\title{
Trophic ecology of the Endangered Darwin's frog inferred by stable isotopes
}

\author{
Blanca E. Molina-Burgos ${ }^{1,2, *}$, Andrés Valenzuela-Sánchez ${ }^{2,3,4}$, \\ Mario Alvarado-Rybak ${ }^{1,2}$, Sebastián Klarian ${ }^{2,5,6}$, Claudio Soto-Azat ${ }^{2,3, *}$ \\ ${ }^{1}$ Programa de Doctorado en Medicina de la Conservación, Facultad de Ciencias de la Vida, Universidad Andres Bello, \\ Santiago 8370251, Chile \\ ${ }^{2}$ Centro de Investigación para la Sustentabilidad, Facultad de Ciencias de la Vida, Universidad Andres Bello, \\ Santiago 8370251, Chile \\ ${ }^{3}$ ONG Ranita de Darwin, Santiago 8330240, Chile \\ ${ }^{4}$ Instituto de Ciencias Ambientales y Evolutivas, Facultad de Ciencias, Universidad Austral de Chile, \\ Avda. Rector Eduardo Morales s/n, Edificio Pugín, Valdivia 5090000, Chile \\ ${ }^{5}$ Centro de Investigacion Marina Quintay, Facultad de Ecología y Recursos Naturales, Universidad Andres Bello, \\ Viña del Mar 2531015, Chile \\ ${ }^{6}$ Laboratorio de Analisis Isotopico, Universidad Andres Bello, Viña del Mar 2531015, Chile
}

\begin{abstract}
Darwin's frogs Rhinoderma spp. are the only known mouth-brooding frogs on Earth. The southern Darwin's frog, $R$. darwinii, is found in the temperate forests of southern South America, is listed as Endangered and could be the only extant representative of this genus. Based on stomach contents, invertebrate prey availability and stable isotope analysis, we determined for the first time trophic ecological parameters for this species. Our results showed that $R$. darwinii is a generalist sit-and-wait predator and a secondary consumer, with a trophic position of 2.9. Carbon and nitrogen isotope composition indicated that herbivore invertebrates are their main prey, detected in $68.1 \%$ of their assimilated food. The most consumed prey included mosquitoes, flies, crickets, grasshoppers and ants. Detritivore and carnivore invertebrates were also ingested, but in lower proportions. Our results contribute to a better understanding of the feeding habits of this fully terrestrial amphibian and provide the first insight into their role linking low forest trophic positions with intermediate predators. We provide valuable biological information for in situ and ex situ conservation which can be used when developing habitat protection, reintroduction and captive breeding programmes. As revealed here, stable isotope analysis is a valuable tool to study the trophic ecology of highly endangered and cryptic species.
\end{abstract}

KEY WORDS: Amphibian $\cdot$ Chile $\cdot$ Conservation $\cdot$ Feeding ecology $\cdot$ Rhinoderma darwinii

\section{INTRODUCTION}

Amphibians are the most threatened vertebrates on Earth (Stuart et al. 2004). Population declines and extinctions of many amphibian species are occurring at an unprecedented rate in numerous regions, mainly due to habitat loss and degradation (Stuart et al. 2004, Catenazzi 2015). A thorough understanding of the natural history of amphibian species, especially their trophic interactions, is critical to determine the impact

*Corresponding authors: csoto@unab.cl,

blancaestela.molina@gmail.com that the documented loss of amphibians will have at the ecosystem level worldwide (Altig et al. 2007, Catenazzi 2015). Dietary information is essential to understand amphibian life history, population fluctuations, assessment of energy flow in food webs and impacts of habitat modification (Solé \& Rödder 2010). In addition, understanding the diet, trophic position and role in food webs is important in determining the most efficient and effective way to protect a species and its habitat (Najera-Hillman et al. 2009, Bishop et al. 2014).

() The authors 2018. Open Access under Creative Commons by Attribution Licence. Use, distribution and reproduction are unrestricted. Authors and original publication must be credited. 
In wildlife, trophic interactions can be studied through the determination of the respective species' diet and foraging behaviour, for which a series of techniques have been developed. These include, but are not restricted to, direct observations of feeding activities, functional morphology, stomach content and faecal analyses, fatty acid profiles and stable isotope analysis (SIA; Fry 2006, Kupfer et al. 2006, Phillips et al. 2014, Cloyed et al. 2015). A combination of these techniques is recommended, since this provides a more comprehensive understanding of the diet and ecological role of the species under study within their respective ecosystems (Hirai \& Matsui 1999, Altig et al. 2007, Bishop et al. 2014). The use of SIA has increased rapidly in the trophic ecology literature during the last 2 decades (Phillips et al. 2014). This technique allows the reconstruction of the diet and determination of trophic positions of species in the food web. Consequently, this is a powerful analytical tool that serves as a complement to classical diet studies, providing information about the partitioning of nutrients into body tissues, and therefore evidence about which prey are assimilated rather than simply ingested (Fry 2006).

Despite the current use of SIA to study the feeding ecology of a wide variety of vertebrates, its application in amphibians has remained limited. This may be in part due to the lack of external structures such as hair, feathers or scales in amphibians, a situation that prevents a simpler, non-invasive or non-lethal approach to these types of studies (Boecklen et al. 2011, Gillespie 2013). So far in amphibians, this technique has been used to (1) study ontogenetic-related changes in the energy transfer from aquatic to terrestrial ecosystems (Kupfer et al. 2006, Verburg et al. 2007), (2) evaluate the diet of tadpoles (Caut et al. 2013, Carreira et al. 2016), (3) quantify the impact of invasive species on native amphibians (Finlay \& Vredenburg 2007, Remon et al. 2016), (4) determine individual-level diet variation of adults (Araújo et al. 2007, 2009, Cloyed \& Eason 2016) and (5) make niche comparisons between sympatric species (Cloyed \& Eason 2017). This technique has also been employed to investigate the dietary requirements of endangered species to inform conservation management (Najera-Hillman et al. 2009, Gillespie 2013, Bishop et al. 2014, Dittrich et al. 2017).

The southern Darwin's frog Rhinoderma darwinii is a fully terrestrial amphibian that inhabits the austral temperate forests of Chile and Argentina (Soto-Azat et al. 2013a). During the last 4 decades, this species has suffered severe population declines and local extinctions. It is currently categorized as Endangered by the IUCN Red List of Threatened Species due to its restricted area of occupancy, severely fragmented populations, ongoing habitat loss, susceptibility to chytridiomycosis and high vulnerability to climate change (Soto-Azat et al. 2013a,b, 2015, Uribe-Rivera et al. 2017, Valenzuela-Sánchez et al. 2017). Its sister species, the northern Darwin's frog $R$. rufum, categorized as Critically Endangered by the IUCN. It has not been observed since 1980 and is considered possibly extinct, in which case $R$. darwinii would be the only extant representative of this genus of mouthbrooding frogs (Soto-Azat et al. 2013a).

Several aspects of $R$. darwinii biology have received attention during the last decade, including studies on natural history, movement and population ecology, biogeography and assessment of threats such as emerging diseases and climate change (Bourke et al. 2010, 2011a,b, Soto-Azat et al. 2013a,b, Valenzuela-Sánchez et al. 2014, 2015, 2017, Valenzuela-Sánchez 2017, Uribe-Rivera et al. 2017). R. darwinii is a diurnal forest-specialist that is found in specific (and well-delimited) areas of undisturbed forest, forming small local populations ( $\mathrm{N}=10$ to 145 frogs; Soto-Azat et al. 2013a, Valenzuela-Sánchez et al. 2015, 2017). This species also exhibits extremely high site fidelity and short movements with average home range of adults of $1.8 \mathrm{~m}^{2}$ (Valenzuela-Sánchez et al. 2014, Valenzuela-Sánchez 2017). However, despite its great relevance for ex situ and in situ conservation, the feeding ecology of this species has not been studied so far. For example, it is not known whether this frog is a dietary specialist. Therefore, the aims of this study were to (1) characterize the diet of $R$. darwinii using multiple techniques including analyses of available prey, gut contents and stable isotopes and (2) determine the trophic position of $R$. darwinii within a terrestrial forest food web.

\section{MATERIALS AND METHODS}

\section{Study area}

Rhinoderma darwinii individuals from 2 sites were studied: Huilo Huilo Private Reserve (3952' 13.74" S, 71 55' 0.06" W, $584 \mathrm{~m}$ a.s.1.) and Puyehue National Park (40³9' 52.30" S, 72 10' 31.60" W, $364 \mathrm{~m}$ a.s.1.), both located in the foothills of the western Andes within the temperate forest of southern Chile, and only separated by $80 \mathrm{~km}$ in a straight line. This ecoregion has a humid temperate climate with 2 dry months in summer (January and February). The average temperature is $11^{\circ} \mathrm{C}$, with annual precipi- 
tation > $2000 \mathrm{~mm}$ and a landscape dominated by Nothofagus trees (austral beeches; Lara et al. 2008).

\section{Sample collection}

Between 2012 and 2015, as part of a long-term $R$. darwinii population monitoring project, 7 recently dead adult individuals were found (Soto-Azat et al. $2013 a, b)$. These included 3 frogs that died from chytridiomycosis and 4 that died from undetermined causes. All the carcasses (3 from Huilo Huilo and 4 from Puyehue) were immediately collected and placed in $70 \%$ ethanol for subsequent analyses. The carcasses were classified as fresh $(<48 \mathrm{~h}$ postmortem), since they showed minimal drying and did not present autolytic changes such as skin peeling, bloating, strong odour or loss of skin pigmentation (Cooper 2012).

In addition, following a microhabitat and a spatial ecology study done in the same area (ValenzuelaSánchez 2017), prey availability was determined from $4 R$. darwinii populations in Huilo Huilo. Invertebrate samples were collected from each of the sites using 2 methods: (1) a single direct diurnal search of $1 \mathrm{~h}$ duration, and (2) through the use of 10 pitfall traps, following the methodology of Work et al. (2002). Searches covered the entire study plot equally, and invertebrate traps were arranged at equal distances from one another. The traps consisted of $500 \mathrm{ml}$ plastic jars filled with $50 \mathrm{ml}$ of water and buried into the ground, which were checked every $24 \mathrm{~h}$ over 3 consecutive days. Based on the body size of $R$. darwinii and following recommendations from other amphibian feeding ecology studies, only invertebrates $\leq 10 \mathrm{~mm}$ in body length were considered for the analyses (Löw \& Török 1998, Work et al. 2002). Field conditions prevented the storage of frozen samples, so all collected invertebrates and frogs were immediately transferred to $70 \%$ ethanol for preservation.

\section{Prey identification}

Once at the laboratory, each $R$. darwinii specimen was ventrally dissected. Stomachs were removed and their contents extracted. Prey items from stomachs and those obtained from the environment were counted, measured for total body length (excluding all types of appendages) and identified to the lowest possible taxonomic level (usually to order or family level) using taxonomic keys (Briones et al. 2012).

\section{Stable isotope analysis}

Approximately $1 \mathrm{mg}$ of femoral muscle tissue from each frog and the same amount from the body of a representative subset of prey items were obtained. We were careful not to include the digestive tract of invertebrates (with the exception of mosquitoes and ants where this was not feasible; in these cases whole bodies were used). In total, 7 tissue samples of $R$. darwinii and 26 invertebrates (individuals), including all prey found in stomach contents $(n=5)$ and a subset from environmental samples $(n=21)$ were analysed (see Table 2). We determined the carbon and nitrogen isotope composition $\left(\delta^{13} \mathrm{C}\right.$ and $\left.\delta^{15} \mathrm{~N}\right)$ of these samples, which indicates the energy source of the consumed food and the trophic position in the food chain, respectively. For lipid extraction from frog tissue, we used a solution of chloroform and methanol (2:1; Hussey et al. 2012). All samples were then dried for $18 \mathrm{~h}$ at $50^{\circ} \mathrm{C}$ and $0.5 \mathrm{mg}$ was used for isotopic determination. The isotope composition was analysed using an elemental analyser (Eurovector) coupled to an isotope ratio mass spectrometer (Nu Instruments). Stable isotope ratios are reported in $\delta$ notation as the deviation from Pee Dee Belemnite for $\delta^{13} \mathrm{C}$ and atmospheric $\mathrm{N}_{2}$ for $\delta^{15} \mathrm{~N}$ (international standards). This ratio of ${ }^{13} \mathrm{C} /{ }^{12} \mathrm{C}$ and ${ }^{15} \mathrm{~N} /{ }^{14} \mathrm{~N}$ was expressed as relative difference per mil (\%), using the equation:

$$
\delta^{13} \mathrm{C} \text { or } \delta^{15} \mathrm{~N}=\left[\left(R_{\text {sample }} / R_{\text {standard }}\right)-1\right] \times 10^{3}
$$

where $R_{\text {sample }}$ and $R_{\text {standard }}$ are the corresponding ratios of heavy to light isotopes $\left({ }^{13} \mathrm{C} /{ }^{12} \mathrm{C}\right.$ and $\left.{ }^{15} \mathrm{~N} /{ }^{14} \mathrm{~N}\right)$ in the sample and the standard, respectively. Typical precision of the analyses was $\pm 0.1 \%$ for both $\delta^{15} \mathrm{~N}$ and $\delta^{13} \mathrm{C}$.

\section{Data analysis}

For the pool of available invertebrates from each of the $4 R$. darwinii populations at Huilo Huilo, we estimated the relative abundance of each taxon. To assess if there were differences in the isotopic signals between prey found in stomach contents and the prey obtained from the environment, a Mann-Whitney test was performed for the isotopic values of $\delta^{13} \mathrm{C}$ and $\delta^{15} \mathrm{~N}$, and significance was set at $\mathrm{p}<0.05$. The proportional contribution of each prey item to the diet of $R$. darwinii was estimated with Bayesian stable isotope mixing models using the MixSIAR package in R (Stock \& Semmens 2013, R Core Team 2014). The model parameters were estimated by running 3 chains of 300000 Markov Chain Monte Carlo itera- 
tions, with a burn-in of 100000 and thinning every 100 observations. Chain convergence was assessed using the Gelman-Rubin Rhat statistic (i.e. Rhat values <1.1). To achieve higher resolution and ecological meaning in mixing models, Phillips et al. (2014) recommended a pooling of production sources with similar isotopic composition and similar ecological roles. Following Briones et al. (2012) and Bishop et al. (2014), the invertebrate prey were grouped according to their diet into carnivores, detritivores and herbivores, and then tested with a 1-way ANOVA to confirm that the isotopic signals of each prey group were well supported. In addition, to determine the trophic enrichment factor (TEF), we used values of $1.3 \pm 0.3 \delta^{13} \mathrm{C}$ and $2.3 \pm 0.18 \delta^{15} \mathrm{~N}$, as proposed by McCutchan et al. (2003).

The trophic position of $R$. darwinii was estimated using the package 'tTrophicPosition' in $\mathrm{R}$, with the option 'Full model' that incorporates the calculation of trophic position of 2 basal organisms and the TEF for nitrogen and carbon (Quezada-Romegialli et al. 2018). For this purpose, we used Orthoptera and Culicidae as a baseline, since both taxa showed the lowest values of nitrogen. To evaluate the dietary preferences of $R$. darwinii, we examined the relationships between the availability of the prey groups and their isotopic contribution in the frog tissue by calculating the Ivlev's electivity index. The purpose of Ivlev's index is to characterize the selectivity of a particular prey item by the consumer under study (Ivlev 1961). The relationship is defined as:

$$
E=\frac{r i-p i}{r i+p i}
$$

where $E$ is the measure of electivity, $r i$ the relative abundance of prey item $i$ in the SIA (as a proportion of the total SIA), and $p i$ is the relative abundance of the same prey item in the environment. To approximate prey availability, we combined all the collected samples from Huilo Huilo. Ivlev's index has a possible range of -1 to +1 , with negative values indicating avoidance or inaccessibility to the prey, zero indicating random selection from the environment, and positive values indicating active selection. $E$ was calculated with the R package 'selectapref' (Richardson 2017).

\section{RESULTS}

\section{Stomach content}

Only 3 out of 7 sampled stomachs and guts contained food ( 2 from Huilo Huilo and 1 from Puyehue).
In these, 5 different prey items ( 1 individual of each) were identified: Calacadia rossi (Amphinectidae: Arachnida), Dasytomorphus ruficollis (Aderidae: Coleoptera), Adalia sp. (Coccinellidae: Coleoptera) and 2 different species of Culicidae (Diptera).

\section{Environmental prey availability}

A total of 335 invertebrate individuals were collected from the surveyed plot with Rhinoderma darwinii at Huilo Huilo. Of these, 89 corresponded to invertebrates of $\leq 10 \mathrm{~mm}$ (and therefore were included in our analyses). These potential prey were identified as belonging to 11 taxonomic families, with the most abundant invertebrates being spiders (Amphinectidae, $36.0 \%$ of prey offer) and mosquitoes (Culicidae, $13.5 \%$ ). The total number of specimens collected and prey richness per site are shown in Table 1.

\section{SIA}

Stable carbon and nitrogen isotopic compositions from the tissue of $R$. darwinii and selected prey items are summarized in Table 2 . The isotopic values of $\delta^{13} \mathrm{C}$ and $\delta^{15} \mathrm{~N}$ reported in prey obtained from stomach contents and environmental availability did not differ significantly (Mann-Whitney $U$-test, $Z=-0.77$, $\mathrm{p}=0.939$ for $\delta^{13} \mathrm{C}$ and $Z=-0.941, \mathrm{p}=0.346$ for $\delta^{15} \mathrm{~N}$ ).

Table 1. Total number (and percentages of total) of potential prey specimens of forest invertebrates collected from sites occupied by 4 populations of Rhinoderma darwinii at Huilo Huilo, south Chile; totals for each category shown in bold

\begin{tabular}{|lcc|}
\hline & N & $\%$ \\
\hline Carnivores & $\mathbf{4 0}$ & $\mathbf{4 4 . 9}$ \\
Amphinectidae & 32 & 36.0 \\
Labiidae & 3 & 3.4 \\
Geophilidae & 5 & 5.6 \\
Detritivores & $\mathbf{1 6}$ & $\mathbf{1 8 . 0}$ \\
Coccinellidae & 2 & 2.2 \\
Forficulidae & 7 & 7.9 \\
Julidae & 7 & 7.9 \\
Herbivores & $\mathbf{3 3}$ & $\mathbf{3 7 . 1}$ \\
Culicidae & 12 & 13.5 \\
Muscidae & 2 & 2.2 \\
Formicidae & 2 & 2.2 \\
Larva Lepidoptera & 5 & 5.6 \\
Acrididae & 6 & 6.7 \\
Gryllidae & 6 & 6.7 \\
Total & 89 & 100 \\
\hline
\end{tabular}


Table 2. Isotopic carbon $\left(\delta^{13} \mathrm{C}\right)$ and nitrogen $\left(\delta^{15} \mathrm{~N}\right)$ compositions in specimens of Rhinoderma darwinii and from prey obtained from stomachs and environmental sampling at sites occupied by the species in south Chile. SD: standard deviation; totals for each category shown in bold

\begin{tabular}{|c|c|c|c|c|c|c|}
\hline Taxon & Common name & $\mathrm{n}$ & $\delta^{13} \mathrm{C}$ & $\delta^{15} \mathrm{~N}$ & $\mathrm{SD} \delta^{13} \mathrm{C}$ & $\mathrm{SD} \delta^{15} \mathrm{~N}$ \\
\hline \multicolumn{7}{|l|}{ Predator } \\
\hline Rhinoderma darwinii & Darwin's frog & 7 & -24.9 & 3.6 & 1.9 & 0.7 \\
\hline \multicolumn{7}{|c|}{ Invertebrate prey groups } \\
\hline Carnivores & & 6 & -24.8 & 4.8 & 0.9 & 0.3 \\
\hline Amphinectidae $^{\mathrm{a}}$ & Spider & 4 & -23.2 & 5.4 & & \\
\hline Labiidae & Earwig & 1 & -24.5 & 4.7 & & \\
\hline Geophilidae & Centipedes & 1 & -24.6 & 3.1 & & \\
\hline Detritivores & & 4 & -28.0 & 2.2 & 2.8 & 0.7 \\
\hline Coleoptera $^{\mathrm{a}}$ & Ladybird, leaf beetle & 2 & -30.3 & 2.1 & & \\
\hline Julidae & Millipede & 1 & -25.7 & 2.4 & & \\
\hline Forficulidae & Earwig & 1 & -28.0 & 2.1 & & \\
\hline Herbivores & & 16 & -25.3 & 1.5 & 2 & 0.6 \\
\hline Lepidoptera larvae & Lepidoptera & 1 & -23.8 & 1.3 & & \\
\hline Culicidae $^{\mathrm{a}}$ & Mosquito & 7 & -22.7 & 1.8 & & \\
\hline Muscidae & Fly & 1 & -24.8 & 1.2 & & \\
\hline Formicidae & Ant & 2 & -24.9 & 1.4 & & \\
\hline Acrididae & Grasshoppers & 3 & -25.0 & 1.3 & & \\
\hline Gryllidae & Cricket & 2 & -24.0 & 1.3 & & \\
\hline
\end{tabular}

Prey groups were well differentiated in terms of isotopic signatures. Thus, there were significant values for $\delta^{15} \mathrm{~N}$ among invertebrate groups (1-way ANOVA, $F=32.11, \mathrm{p}<0.001)$, but not for $\delta^{13} \mathrm{C}(1$-way ANOVA, $F=2.61, \mathrm{p}=0.095)$, the latter reflecting no difference in habitat used among the 3 groups. $R$. darwinii individuals had slightly more enriched $\delta^{15} \mathrm{~N}$ values than all invertebrates $(3.6 \pm 0.7 \%$ ) , except for carnivore invertebrates, indicating that the frogs feed mostly on the herbivore and detritivore groups (Table 2). Fig. 1 shows the results of the isotope signals of frogs and their prey, with TEF-adjusted isotope values for the frogs. The isotopic signal of $\delta^{13} \mathrm{C}$ is reduced to the range of -27 to $-23 \%$, an isotopic range representing a diet entirely of terrestrial origin. In general, the $\delta^{13} \mathrm{C}$ and $\delta^{15} \mathrm{~N}$ isotopic composition of prey groups provided a clear split between carnivore invertebrates and the other prey groups. Carnivore invertebrates presented the most reduced range of $\delta^{13} \mathrm{C}$ and $\delta^{15} \mathrm{~N}$, indicating a reduced trophic behaviour associated with a higher specialization of their diet. In contrast, detritivore and herbivore invertebrates presented a considerable overlap in their $\delta^{13} \mathrm{C}$ and $\delta^{15} \mathrm{~N}$ isotopic signals, suggesting trophic similarity between some species within these groups. Also, the wide range of $\delta^{13} \mathrm{C}$ shown by herbivore and detritivore invertebrates indicated that these organisms obtain their food from different types of primary producers (Fig. 1). The values of $\delta^{13} \mathrm{C}$ in $R$. darwinii pre-

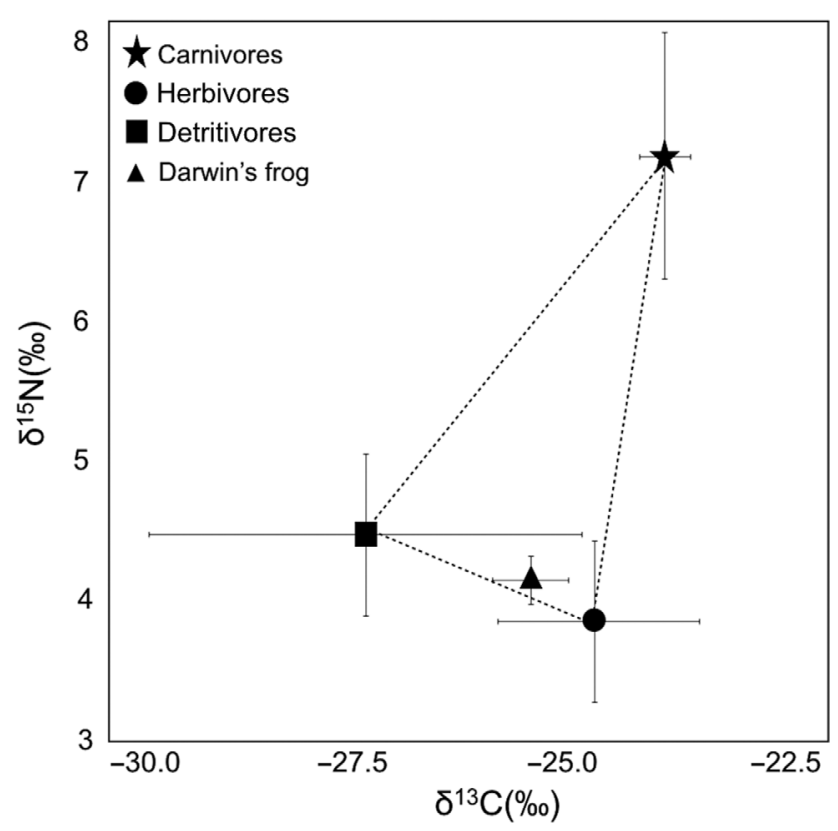

Fig. 1. Stable isotope signatures of $\delta^{13} \mathrm{C}$ and $\delta^{15} \mathrm{~N}$ of Rhinoderma darwinii (triangles) from south Chile. Prey data are their potential dietary items + trophic enrichment factor (TEF); error bars: $\pm 1 \mathrm{SD}$

sented isotopic signals within the range values of herbivore prey, which are in accordance with the results of the isotopic model showing that invertebrate herbivores were the predominant prey in the 


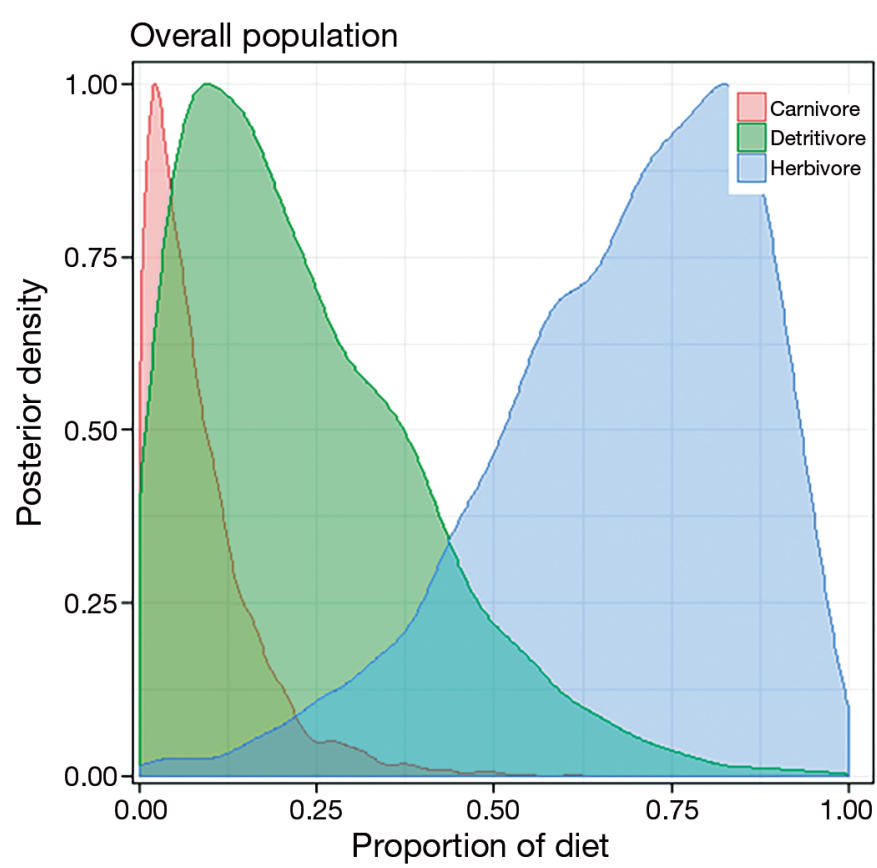

Fig. 2. Posterior density distribution of the proportion of assimilated diet per prey group in Rhinoderma darwinii estimated with a Bayesian isotopic mixing model

Table 3. Ivlev's selectivity index, comparing Rhinoderma darwinii diet obtained from stable isotope analysis (SIA; values are mean $\pm \mathrm{SD}$ ) with the relative abundance of prey available in the environment

\begin{tabular}{|lccc|}
\hline $\begin{array}{c}\text { Invertebrate } \\
\text { prey group }\end{array}$ & SIA (\%) & $\begin{array}{c}\text { Prey } \\
\text { available }(\%)\end{array}$ & $\begin{array}{c}\text { Ivlev's } \\
\text { Index }(E)\end{array}$ \\
\hline Carnivore & $8.4 \pm 8.0$ & 44.9 & -0.69 \\
Detritivore & $23.6 \pm 17$ & 18.0 & 0.14 \\
Herbivore & $68.1 \pm 17.7$ & 37.1 & 0.29 \\
\hline
\end{tabular}

diet of $R$. darwinii, representing $68.1 \pm 18.5 \%$ of their assimilated food. The most consumed prey included mosquitoes, flies, crickets, grasshoppers and ants. Another $23.6 \pm 17.0 \%$ of the diet was from the consumption of detritivore invertebrates, while carnivores contributed $8.4 \pm 8.0 \%$ (Fig. 2). The trophic position calculated for $R$. darwinii was 2.9 , which indicates that $R$. darwinii is a secondary consumer. The relationships of feeding patterns and prey availability using Ivlev's selectivity index showed that the species does not actively select its prey (Table 3).

\section{DISCUSSION}

This is the first study to provide insights into the trophic ecology of Rhinoderma darwinii. By using stomach contents, environmental prey availability and stable isotope techniques, we were able to (1) determine the contribution of different prey in the assimilated diet of $R$. darwinii, (2) provide evidence that this species exhibits a generalist predatory behaviour and (3) show that they are secondary consumers. Our results contribute to a further understanding of the ecology of $R$. darwinii, of community interactions within their environment and of the potential impact of habitat modification, as well as to informing in situ and ex situ conservation of this Endangered species. Determining the diet and trophic position of $R$. darwinii serves as a baseline for aiding in reintroduction and restoration projects, and provides useful information to improve captive management.

Our study showed that herbivore, detritivore and carnivore invertebrates play differential roles in the diet of $R$. darwinii. Although highly abundant in the environment, consumption of carnivore invertebrates was lower, as shown by the low proportion in the assimilated food of $R$. darwinii. In contrast, there was no evidence for major selection among herbivore and detritivore invertebrates, approximately reflecting their proportions in abundance in the environment (Table 3). This reduced consumption of carnivore invertebrates (i.e. spiders) by $R$. darwinii may be the result of that prey's behaviour (e.g. rapid movement, active defence, nocturnal habits), which can be effective against predation (Wirsing et al. 2010). It is important to note that spiders collected from the environment and included in the analyses varied little in size and were all slightly under the $10 \mathrm{~mm}$ cut-off point of inclusion criteria (range: 8.5 to $9.5 \mathrm{~mm}$ ), therefore spiders were considerably larger than other prey. Also, spiders are characterized by having long appendages, which were not considered here in the body size measurement. Therefore, it might be possible that this type of prey was not readily consumed due to its size. Overall, our results suggest that $R$. darwinii exhibits a generalist predatory behaviour, since they feed on different types of invertebrates associated with the detritus and vegetation found in their habitat. This is consistent with previous observations showing a sit-and-wait predatory behaviour in $R$. darwinii (Crump 2002), a strategy that might be used by some generalist and cryptic animals to avoid energy loss when searching for food and to prevent predation (see Video S1 in the Supplement at www.int-res.com/articles/suppl/n036 p269_supp/).

R. darwinii has a scattered distribution within the native forest it inhabits, forming relatively welldelimited local populations (Crump 2002, Soto-Azat 
et al. 2013a, Valenzuela-Sánchez et al. 2014). Habitat selection by this species is not well understood and it is possible that the availability of suitable prey items plays some role. Our data shows that the relative abundance of invertebrate herbivores (>40\%) is higher than that of other prey groups at sites occupied by $R$. darwinii (Table 1), suggesting that the abundance and composition of invertebrate communities may be important factors for habitat selection, for instance influencing settlement decisions during juvenile dispersal (Valenzuela-Sánchez 2017). Further studies to better understand key factors regarding habitat selection, including food resources, are required - particularly for improving in situ conservation management and reintroduction programmes (Bishop et al. 2014).

Prior to this study, the only reference to $R$. darwinii diet was that of Wilhelm $(1927$, p. 13), who described from stomach contents 'the presence of insects of the genus Musca, Hiperalomia, Tipulidas, Agrion, Perla, Gyrinus, Aechna, and Cordulia'; however, some of these taxonomic classifications are no longer in use. After analysing for taxonomic changes (Camousseight \& Vera 2007, Briones et al. 2012), we identified that these invertebrates correspond mainly to medium- to large-sized flying insects. Since Wilhelm's (1927) vague description and because no information on location, number of analysed stomachs, prey abundance or prey life stages were provided, it is not possible to compare those findings with our results.

Darwin's frogs are of high conservation concern: of the 2 species, one, $R$. darwinii, is Endangered, and the other, $R$. rufum, has not been observed in the wild for the last 4 decades (Soto-Azat et al. 2013a,b). Thus, existing ex situ conservation initiatives in Chile have focused on the captive breeding of $R$. darwinii, aiming to safeguard assurance colonies of the species, and also to establish analogous captive breeding protocols in case $R$. rufum is rediscovered and captive breeding is required (Fabry \& Tirado-Sepúlveda 2012, Ortiz et al. 2012). In this context, information on the diet of $R$. darwinii comes from the experience of captive breeding projects. Between 1985 and 2007, the Zoologisches Forschungsmuseum Alexander Koenig in Bonn, Germany, was the first to establish a long-term captive breeding programme for $R$. darwinii. More recently, 2 other projects were established in Chile at the University of Concepción (Ortiz et al. 2012) and Zoológico Nacional (Fabry \& Tirado-Sepúlveda 2012), in 2009 and 2010 respectively. In these, the most frequently used prey to feed $R$. darwinii includes small crickets (Gryllus and Achaeta), fruit flies (Drosophila), aphids
(Acer and Aphis), woodlice (Porcellia) and springtails (Collembola; Busse 2004, Ortiz et al. 2012). Although relevant for animal husbandry, many of these food items are not found naturally in Rhinoderma habitat. Also, it is unclear how different dietary compositions may affect individual fitness in this species. Gillespie (2013), studying the feeding ecology of the threatened salamander Eurycea sosorum in Texas using stable isotopes, suggested that feeding a combination of prey items should improve the success of captive breeding of that species. Likewise, Ogilvy et al. (2012) found a higher fecundity in female Agalychnis callidryas frogs raised on diets enriched with carotenoids compared to controls. In addition, a carotenoid-enriched diet has been shown to be beneficial for the bacterial community associated with the skin of captive A. callidryas, having important implications for the suitability of populations intended for reintroductions (Antwis et al. 2014). Dietary information from locally imperiled species is a necessary component in designing management and conservation programmes (Solé \& Rödder 2010). For instance, stable isotope studies have been a key aspect in assessing the success of reintroduction programmes in Przewalski's horses Equus ferus przewalskii (Kaczensky et al. 2017) and bald eagles Haliaeetus leucocephalus (Newsome et al. 2015). In amphibians, monitoring Australian green and golden bell frogs Litoria aurea subjected to conservation management has shown a reduction in reproduction in reintroduced frogs from created habitat compared to surrounding wild populations, probably associated with a reduced diversity of invertebrate prey in the created habitat. Therefore, determining with precision the invertebrates on which $R$. darwinii preys on in nature will help in the assessment of habitat for translocations and other in situ conservation habitat management practices (e.g. habitat restoration), while at the same time providing very useful information for captivebreeding conservation purposes (Najera-Hillman et al. 2009, Gillespie 2013, Bishop et al. 2014).

The carbon isotopic signal showed that the primary carbon source in $R$. darwinii corresponds to $\mathrm{C}_{3}$ plant photosynthetic pathways. These plants have a carbon isotopic composition of around -28\% (Fry 2006) and are the dominant species in the austral temperate forests of Chile and Argentina (e.g. Nothofagus spp.). $\mathrm{C}_{3}$ plants are associated with humid environments in which $\mathrm{CO}_{2}$ capture requires less energy expenditure (Peri et al. 2012). Although the terrestrial origin of the diet of $R$. darwinii was evident, the variation in the isotope values of $\delta^{13} \mathrm{C}$ can be indicative of the variation of the diet at the individual level 
due to differences in the use of available resources by the frogs (Araújo et al. 2009).

In contrast, $\delta^{15} \mathrm{~N}$ from $R$. darwinii tissue presented a reduced range, indicating that their prey occupies the same trophic position in the ecosystem. Our estimated concentration of $\delta^{15} \mathrm{~N}$ for $R$. darwinii $(3.6 \pm$ $0.7 \%$ ) was lower than that reported in other feeding ecology studies of amphibians. Studying several species of terrestrial frogs of 6 genera from Panama, Verburg et al. (2007) reported average $\delta^{15} \mathrm{~N}$ values of $5.5 \%$. Also, adult Rana macrodactyla from the tropical forests of Thailand had a $\delta^{15} \mathrm{~N}$ isotopic signal of about $6 \%$ (Kupfer et al. 2006). These observed differences in the values of isotopic nitrogen may reflect possible differences in baseline $\delta^{15} \mathrm{~N}$ of their respective food webs, rather than a difference in trophic roles. Consequently, all these species were identified as secondary consumers (primarily preying on herbivore invertebrates) and with similar trophic positions. Lower levels of $\delta^{15} \mathrm{~N}$ in $R$. darwinii can possibly be attributed to the type of prey consumed, which presented low concentrations of $\delta^{15} \mathrm{~N}(1.5 \pm 0.6 \%)$. Leiopelma hochstetteri frogs from New Zealand are reported to feed primarily on terrestrial invertebrates, including spiders, presenting a $\delta^{15} \mathrm{~N}$ of $4.1 \pm$ $0.2 \%$ (Najera-Hillman et al. 2009). Similar results to ours were reported for Hoplobatrachus rugulosus frogs raised in frog farms in Vietnam, with average $\delta^{15} \mathrm{~N}$ values of $3.5 \%$ o (Dittrich et al. 2017). In that study, the authors postulated that the low $\delta^{15} \mathrm{~N}$ concentration was associated with a restricted consumption of animal protein in captivity. In our case, the low values of $\delta^{15} \mathrm{~N}$ found in $R$. darwinii can be explained by their predominant intake of prey that does not consume animal proteins (i.e. herbivores).

Among the main caveats of our study is the small sample size of stomachs and frog tissue for SIA. However, this is a common problem when dealing with cryptic and endangered species (Najera-Hillman et al. 2009). Another criticism concerns the use of ethanol for sample preservation, since it can interfere with the isotopic signal of $\delta^{13} \mathrm{C}$ and $\delta^{15} \mathrm{~N}$, potentially causing a change in its values (Sarakinos et al. 2002, Stallings et al. 2015, Kishe-Machumu et al. 2017). However, this impact is considered to be minimal since our invertebrate samples were all treated in the same way and only maintained in ethanol for $1 \mathrm{wk}$ prior to being processed in the laboratory. Ethanol is a widely used preservative in feeding ecology studies (Marcus et al. 2017), and our field conditions did not allow for freezing the samples. Another potential source of variation is the $4 \mathrm{yr}$ time span over which samples were collected. While isotopic baselines may change over this window of time, we believe this potential impact is negligible since the environments inhabited by $R$. darwinii exhibit a high level of spatiotemporal homogeneity (Soto-Azat et al. 2013a). In addition, following Phillips et al. (2014) we grouped prey by their foraging behaviours in our mixing model analyses, thus minimizing any possible effect of a change in availability of a specific taxon during this period of time.

Our study provides a better understanding of the role of $R$. darwinii in the austral temperate forests of South America. The results of the trophic position of $R$. darwinii revealed their importance in the transfer of nutrients along the food chain, linking low trophic positions with intermediate predators. Although we provided information on the food web structure of $R$. darwinii, it is important for future studies to expand the spectrum of studied species to higher trophic positions to integrate potential predators (e.g. birds or reptiles) or other species of anurans sympatric to $R$. darwinii, as well as to lower trophic levels to comprehend the variety of primary producers in this trophic system. The use of stable isotopes provides a robust methodology to determine ingested and assimilated food, as well as information on the trophic position of the species under study (Davis et al. 2012). The use of SIA enables us to obtain relevant dietary information, and together with complementary data (i.e. stomach content analysis and prey availability), is a recommended approach when working with highly threatened and cryptic species, from which specimens can be difficult to obtain (Gillespie 2013).

\section{CONCLUSIONS}

This study revealed relevant aspects of the feeding ecology of Rhinoderma darwinii. This frog occupies the position of a secondary consumer in its food web and exhibits a generalist behaviour, feeding mainly on different terrestrial herbivore invertebrates. EX situ and in situ conservation management, based on captive breeding, animal reintroductions and habitat protection, will benefit from the information generated here. More broadly, this study illustrates how the stable isotope technique allows the generation of robust information on trophic ecology in imperiled species.

Acknowledgements. We thank Dr. Mauricio GonzálezChang for his contribution to invertebrate identification and Sally Wren for the revision of an earlier version of the manuscript. We are also extremely grateful to Tomás Elgueta Alvarez for providing Video S1. B.E.M.B. has a fellowship 
awarded by Universidad Andres Bello. This research project was approved by the Bioethics Committee at the Universidad Andres Bello, Chile $\left(\mathrm{N}^{\circ} 13 / 2015\right)$, and by permits $\mathrm{N}^{\circ} 5666 / 2013, \mathrm{~N}^{\circ} 230 / 2015$, and $\mathrm{N}^{\circ} 212 / 2016$ of the Chilean Agriculture and Livestock Service, and $N^{\circ} 026 / 2013$ and $N^{\circ} 11 / 2015$ IX of the Chilean National Forestry Corporation. This study was funded by the Dirección General de Investigación y Doctorados, Universidad Andres Bello, through grant $\mathrm{N}^{\circ} \mathrm{DI}-53-11 / \mathrm{R}$ and national funds through FONDE CYT N 11140902 and 1181758 (to C.S.A.).

\section{LITERATURE CITED}

Altig R, Whiles MR, Taylor CI (2007) What do tadpoles really eat? Assessing the trophic status of an understudied and imperiled group of consumers in freshwater habitats. Freshw Biol 52:386-395

Antwis RE, Haworth RL, Engelmoer DJP, Ogilvy V, Fidgett AL, Preziosi RF (2014) Ex situ diet influences the bacterial community associated with the skin of red-eyed tree frogs (Agalychnis callidryas). PLOS ONE 9:e85563

Araújo MS, Bolnich DI, Machado G, Giaretta AA, dos Reis SF (2007) Using $\delta^{13} \mathrm{C}$ stable isotopes to quantify individual-level diet variation. Oecologia 152:643-654

Araújo MS, Bolnich DI, Martinelli LA, Giaretta AA, dos Reis SF (2009) Individual-level diet variation in four species of Brazilian frogs. J Anim Ecol 78:848-856

* Bishop MR, Drewes RC, Vredenburg VT (2014) Food web linkages demonstrate importance of terrestrial prey for the threatened California red-legged frog. J Herpetol 48: 137-143

Boecklen WJ, Yarnes CT, Cook BA, James AC (2011) On the use of stable isotopes in trophic ecology. Annu Rev Ecol Evol Syst 42:411-440

Bourke J, Mutschmann F, Ohst T, Ulmer P and others (2010) Batrachochytrium dendrobatidis in Darwin's frog Rhinoderma spp. in Chile. Dis Aquat Org 92:217-221

Bourke J, Barrientos C, Ortiz JC, Böhme W, Bakker TCM (2011a) Colour change in Darwin's frogs (Rhinoderma darwinii, Duméril and Bibron, 1841) (Anura: Rhinodermatidae). J Nat Hist 45:2661-2668

Bourke J, Busse K, Bakker TCM (2011b) Sex differences in polymorphic body coloration and dorsal pattern in Darwin's frogs (Rhinoderma darwinii). Herpetol J 21: $227-234$

Briones R, Gárate F, Jerez V (2012) Insectos de Chile nativos, introducidos y con problemas de conservación, Guía de Campo. Corporación Chilena de la Madera, Concepción

Busse K (2004) Biología de la reproducción del Sapito de Darwin (Rhinoderma darwinii) y su cría en cautividad. In: Iriarte A, Tala C, González B, Zapata B, González G, Maino M (eds) Cría en cautividad de fauna Chilena. University of Chile, Santiago, p 139-146

Camousseight A, Vera A (2007) Estado del conocimiento de los Odonata (Insecta) de Chile. Bol Mus Nac Hist Nat 56: 119-132

Carreira BM, Segurado P, Orizaola G, Gonçalves N, Pinto V, Laurila A, Rebelo R (2016) Warm vegetarians? Heat waves and diet shifts in tadpoles. Ecology 97:2964-2974

Catenazzi A (2015) State of the world's amphibians. Annu Rev Environ Resour 40:91-119

Caut S, Angulo E, Díaz-Paniagua C, Gomez-Mestre I (2013) Plastic changes in tadpole trophic ecology revealed by stable isotope analysis. Oecologia 173:95-105

Cloyed CS, Eason PK (2016) Different ecological conditions support individual specialization in closely related, ecologically similar species. Evol Ecol 30:379-400

Cloyed CS, Eason PK (2017) Niche partitioning and the role of intraspecific niche variation in structuring a guild of generalist anurans. R Soc Open Sci 4:170060

Cloyed CS, Newsome SD, Eason PK (2015) Trophic discrimination factors and incorporation rates of carbon- and nitrogen-stable isotopes in adult green frogs, Lithobates clamitans. Physiol Biochem Zool 88:576-585

Cooper J (2012) The estimation of post-mortem interval (PMI) in reptiles and amphibians: current knowledge and needs. Herpetol J 22:91-96

Crump M (2002) Natural history of Darwin's frog Rhinoderma darwinii. Herpetol Nat Hist 9:21-30

* Davis AM, Blanchette ML, Pusey BJ, Jardine TD, Pearson RJ (2012) Gut content and stable isotope analyses provide a complementary understanding of ontogenetic dietary shifts and trophic relationships among fishes in a tropical river. Freshw Biol 57:2156-2172

* Dittrich C, Struck U, Rödel MO (2017) Stable isotope analyses-a method to distinguish intensively farmed from wild frogs. Ecol Evol 7:2525-2534

Fabry M, Tirado-Sepúlveda M (2012) Rol del zoológico nacional en la conservación de los anfibios de Chile. In: Soto-Azat C, Valenzuela-Sánchez A (eds) Conservación de anfibios de Chile. Universidad Nacional Andrés Bello, Santiago, p 84-85

Finlay JC, Vredenburg VT (2007) Introduced trout sever trophic connections in watersheds: consequences for a declining amphibian. Ecology 88:2187-2198

Fry B (2006) Stable isotope ecology. Springer, New York, NY

Gillespie JH (2013) Application of stable isotope analysis to study temporal changes in foraging ecology in a highly endangered amphibian. PLOS ONE 8:e53041

Hirai T, Matsui M (1999) Feeding habits of the pond frog, Rana nigromaculata, inhabiting rice fields in Kyoto, Japan. Copeia 4:949-947

*Hussey NE, MacNeil MA, Olin JA, McMeans BC, Kinney MJ, Chapman DD, Fisk AT (2012) Stable isotopes and elasmobranchs: tissue types, methods, applications and assumptions. J Fish Biol 80:1449-1484

Ivlev VS (1961) Experimental ecology of the feeding of fish. Yale University Press, New Haven, CT

KKaczensky P, Burnik Šturm M, Sablin MV, Voigt CC and others (2017) Stable isotopes reveal diet shift from preextinction to reintroduced Przewalski's horses. Sci Rep 7: 5950

KKishe-Machumu MA, van Rijssel JO, Poste A, Hecky RE, Witte F (2017) Stable isotope evidence from formalin-ethanol-preserved specimens indicate dietary shifts and increasing diet overlap in Lake Victoria cichlids. Hydrobiologia 791:155-173

KKupfer A, Langel R, Scheu S, Himstedt W, Maraun M (2006) Trophic ecology of a tropical aquatic and terrestrial food web: insights from stable isotopes $\left(\delta^{15} \mathrm{~N}\right)$. J Trop Ecol 22: 469-476

K Lara A, Villalba R, Urrutia R (2008) A 400-year tree-ring record of the Puelo River summer-fall streamflow in the Valdivian Rainforest ecoregion, Chile. Clim Change 86: 331-356

Löw P, Török J (1998) Prey size selection and food habits of water frogs and moor frogs from Kis-Balaton, Hungary. Herpetozoa (Wien) 11:71-78 
Marcus L, Virtuem P, Nichols PD, Meekan MG, Pethybridge $H$ (2017) Effects of sample treatment on the analysis of stable isotopes of carbon and nitrogen in zooplankton, micronekton and a filter feeding shark. Mar Biol 164:124

McCutchan JH Jr, Lewis WM, Kendall C, McGrath CC (2003) Variation in trophic shift for stable isotope ratios of carbon, nitrogen, and sulfur. Oikos 102:378-390

Najera-Hillman E, Alfaro AC, Breen BB, O'Shea S (2009) Characterization $\left(\delta^{13} \mathrm{C}\right.$ and $\delta^{15} \mathrm{~N}$ isotopes) of the food webs in a New Zealand stream in the Waitakere Ranges, with emphasis on the trophic level of the endemic frog Leiopelma hochstetteri. N Z J Zool 36:165-176

Newsome SD, Collins PW, Sharp P (2015) Foraging ecology of a reintroduced population of breeding bald eagles on the Channel Islands, California, USA, inferred from prey remains and stable isotope analysis. Condor 117:396-413

Ogilvy V, Preziosi RF, Fidgett AL (2012) A brighter future for frogs? The influence of carotenoids on the health, development and reproductive success of the red-eye tree frog. Anim Conserv 15:480-488

Ortiz JC, Barrientos C, Bourke J (2012) Proyecto cría ex situ de la ranita de Darwin. In: Soto-Azat C, ValenzuelaSánchez A (eds) Conservación de anfibios de Chile. Universidad Nacional Andrés Bello, Santiago, p 87-92

Peri PL, Ladd B, Pepper DA, Bonser SP, Laffan SW, Amelung $\mathrm{W}(2012)$ Carbon $\left(\delta^{13} \mathrm{C}\right)$ and nitrogen $\left(\delta^{15} \mathrm{~N}\right)$ stable isotope composition in plant and soil in Southern Patagonia's native forests. Glob Change Biol 18:311-321

Phillips DL, Inger R, Bearhop S, Jackson AL and others (2014) Best practices for use of stable isotope mixing models in food-web studies. Can J Zool 92:823-835

Q Quezada-Romegialli C, Jackson AL, Hayden B, Kahilainen KK, Lopes C, Harrod C (2018) tRophicPosition: Bayesian trophic position calculation with stable isotopes. $\mathrm{R}$ package version 0.7.5. https://cran.r-project.org/package= tRophicPosition

R Core Team (2014) R: a language and environment for statistical computing. R Foundation for Statistical Computing, Vienna

*Remon J, Bower DS, Gaston TF, Clulow J, Mahony MJ (2016) Stable isotope analyses reveal predation on amphibians by a globally invasive fish (Gambusia holbrooki). Aquat Conserv: Mar Freshw Ecosyst 26:724-735

Richardson J (2017) Analysis of field and laboratory foraging 'selectapref' R package version. https://CRAN.R-project.org/package $=$ selectapref

Sarakinos HS, Johnson ML, Vander Zanden MJ (2002) A synthesis of tissue-preservation effects on carbon and nitrogen stable isotope signatures. Can $\mathrm{J}$ Zool 80: 381-387

Solé M, Rödder D (2010) Dietary assessments of adult amphibians. In: Dodd K (ed) Amphibian ecology and conservation: a handbook of techniques. Oxford University Press, Oxford, p 167-184

Soto-Azat C, Valenzuela-Sánchez A, Collen B, Rowcliffe JM, Veloso A, Cunningham AA (2013a) The population

Editorial responsibility: Michael Mahony, Callaghan, New South Wales, Australia decline and extinction of Darwin's frogs. PLOS ONE 8: e66957

Soto-Azat C, Valenzuela-Sánchez A, Clarke BT, Busse K, Ortiz JC, Barrientos C, Cunningham AA (2013b) Is chytridiomycosis driving Darwin's frogs to extinction? PLOS ONE 8:e79862

Soto-Azat C, Valenzuela-Sánchez A, Ortiz JC, Díaz-Páez H and others (2015) ASG Chile leads update of the extinction risk of Chilean amphibians for the IUCN Red List of Threatened Species ${ }^{\mathrm{TM}}$. FrogLog 116:6-7

Stallings CD, Nelson JA, Rozar KL, Adams CS and others (2015) Effects of preservation methods of muscle tissue from upper-trophic level reef fishes on stable isotope values $\left(\delta^{13} \mathrm{C}\right.$ and $\left.\delta^{15} \mathrm{~N}\right)$. PeerJ 3:e874

Stock BC, Semmens BX (2013) MixSIAR GUI user manual, version 3.1. https://github.com/brianstock/MixSIAR/

* Stuart SN, Chanson JS, Cox NA, Young BE, Rodrigues ASL, Fischman DL, Waller RW (2004) Status and trends of amphibian declines and extinctions worldwide. Science 306:1783-1786

Kuribe-Rivera DE, Soto-Azat C, Valenzuela-Sánchez A, Bizama G, Simonetti JA, Pliscoff P (2017) Dispersal and extrapolation on the accuracy of temporal predictions from distribution models for the Darwin's frog. Ecol Appl 27:1633-1645

Valenzuela-Sánchez A (2017) Is chytridiomycosis a threat to the Darwin's frog (Rhinoderma darwinii)? A multiapproach disease risk assessment. $\mathrm{PhD}$ thesis, Universidad Andrés Bello, Santiago

* Valenzuela-Sánchez A, Harding G, Cunningham A, Chirgwin C, Soto-Azat C (2014) Home range and social analyses in a mouth-brooding frog: testing the coexistence of paternal care and male territoriality. J Zool (Lond) 294: 215-223

*Valenzuela-Sánchez A, Cunningham AA, Soto-Azat C (2015) Geographic body size variation in ectotherms: effects of seasonality on an anuran from the southern temperate forest. Front Zool 12:37

*Valenzuela-Sánchez A, Schmidt BR, Uribe-Rivera DE, Costas F, Cunningham AA, Soto-Azat C (2017) Cryptic disease-induced mortality may cause host extinction in an apparently-stable host-parasite system. Proc R Soc B 284:20171176

Verburg P, Kilham SS, Pringle CM, Lips KR, Drake DL (2007) A stable isotope study of a Neotropical stream food web prior to the extirpation of its large amphibian community. J Trop Ecol 23:643-651

Wilhelm O (1927) La Rhinoderma darwinii D. y B. Bol Soc Biol Concepc 1:11-39

*Wirsing AJ, Cameron KE, Heithaus MR (2010) Spatial responses to predators vary with prey escape mode. Anim Behav 79:531-537

* Work TT, Buddle CM, Korinus LM, Spence JR (2002) Pitfall trap size and capture of three taxa of litter-dwelling arthropods: implications for biodiversity studies. Environ Entomol 31:438-448

Submitted: October 22, 2017; Accepted: May 22, 2018 Proofs received from author(s): July 24, 2018 